\title{
Genetic variation of sweet com inbreds on seedling emergence by Fusarium moniliforme infection
}

\author{
Tae-Ho Han* \\ Institution of Agricultural Science and Technology \\ Chonnam National University Gwangju 500-757 South Korea \\ *Corresponding author: hanth@jnu.ac.kr
}

요 약

마름병에 감염된 옥수수 종자는 마름병 발병율을 높이고 재배지에서 감염율을 높이게 된다. 식용 및 사료용 옥수수 계통 종자 역시 F. moniliforme에 감염된 경우가 있다. 일반적으로 F. moniliforme는 종자를 썩게 만들지만, 외면상으로 감염이 확인되지 않아 보이면서 건강하게 보 이는 종자들이 종종 발견된다. 식용 단옥수수 계통들 중에서 F. moniliforme에 감염되었으나 저항성을 보이며 충실한 발아력을 가진 경우가 발견되었다. 본 연구에서는 su1, se1, sh2 육종 계통들을 대상으로 인위적으로 F. moniliforme에 감염시키고 발아력을 측정하여 유전적 다양 성을 조사하였다. F. moniliforme에 감염 후 저항성 기작을 확인하였으며, 발아를 촉진하는 경 우도 발견되었다.

Additional key words: Fusarium moniliforme, Germination, Germplasm, Mutation, Plant breeding

Introduction

On sweet corn F. moniliforme has been reported to cause stalk rot, leaf spot, ear and kernel rot, damping-off, and seedling blight (Christensen and Wilcoxson, 1966; Shurtleff, 1977). Planted infected seed may increase the incidence of seedling blight (Furtell and Kilgore, 1969) and contribute to systemic infection of plants (Foley, 1962). Although F. moniliforme causes a kernel rot, the pathogen is often found in healthy kernels that appear to be physically undamaged (Koehler, 1942; Thomas and Buddenhagen, 1980). Sixty inbreds of field or dent corn sampled in California, all had kernels infected with F. moniliforme (Smith and Madson, 1949).

Sweet corn inbreds have been identified that exhibit partial resistance to kernel infection by $F$. moniliforme and good emergence (Headrick and Pataky, 1989). Headrick et al. (1989) found genotypic variation for $F$. moniliforme susceptibility among su1, sh2 and se1 inbreds.

The sugary enhancer (se1) gene is a recessive modifier of the su1 endosperm mutation (Ferguson et al., 1979). When homozygus, the se1 allele increase total sugars in su1 kernels to levels comparable to those found sh2 kernels without a 
reduction in phytoglycogen content (Gonzales et al., 1974; 1976). Shrunken2 (sh2) hybrids have two to three times more sugar and one third less starch than sugary1 (su1) hybrids from 16 to 28 days after pollination (DAP) (Creech, 1965). Shrunken2 hybrids also have a higher moisture content and 10 to $20 \%$ of phytoglycogen observed in sugary1 hybrids (Garwood et al., 1976; Dickson et al., 1983).

Despite of the desirable attribute of the se 1 and sh2 endosperm types, the significant reduction has hindered their commercial utilization (Douglass et al., 1993; Soberalske and Andrew, 1978; Wolf and Showalter, 1974). A number of kernel characters have been suggested as important in the poor emergence and seedling vigor associated with the sh2 and se1 endosperm mutations including; susceptibility of kernels in infection by fungal pathogens (Berger and Wolf, 1974; Futtrel and Kigore, 1969; Simon, 1978), especially F. moniliforme (Headrick and Pataky, 1989).

The work described in this study had been designed to evaluate a genetically diverse set of sweet corn inbreds for resistance to $F$. moniliforme infection with either su1, se1 and sh2 endosperm mutations. It will also identify promising parents on seedling emergence in breeding programs aimed to develop improved sweet corn germplasm.

\section{Material and Methods}

\section{Plant Material}

Seed of 25 sweet corn inbreds (8 su1, 8 se1, 9 sh2) were provided from the sweet corn breeding program in the Department of Horticulture at the University of Illinois (Table 1). Inoculation condition and procedure was detailed in Han (submitted).

\section{Germination Test Procedure}

Kernels of both the inoculated and control (non-inoculated) ears from each inbred were partitioned visually into 3 groups: 1) kernels without visual sign of the pathogen, 2) kernels with visual sign and 3) kernels with broken pericarps or with signs of other diseases. The percentage of kernels with visual sign and without visual sign for each treatment and inbred was determined by dividing the number of kernels with and without signs of $F$. moniliforme by the total number of kernels. The occurrence of either white or pink mycelium was defined as sign of the pathogen. Kernels that were broken or showed signs of other disease were excluded from consideration in this experiment. Percentages of seeds in each group for each inbred were calculated to provide a unreplicated evaluation of ear susceptibility to inoculation.

A germination test was conducted with both the inoculated and non-inoculated seeds. Control and inoculated seeds were used to isolate the effect of F. moniliforme inoculation from other genetic and physiological influences on germination and seedling emergence. The effect of $F$. moniliforme infection was determined by the inoculated by the control treatment.

Three replications of 50 seeds from both treatment of each inbred were tested for germination by using a standard soil germination test (Jangulo, 1988). Fifty seeds were prepared in a ratio of kernels with and without visual sign of the pathogen observed in the bulked seed lot of each inbred and treatment. Ground bed soil [10 parts coarse quartz sand, (Best Sand Co. \#620) and three parts silty clay loam soil by volume] uniformly mixed with the aid of a rotary cement mixer was sterilized before use and placed in plastic shoe boxes (Rubbermaid) measuring $31 \mathrm{~cm} \times 165 \mathrm{~cm} \times 9 \mathrm{~cm}$. Fifty seeds were placed on top of $2.5 \mathrm{~cm}$ of sterilized soil using a plastic form, precut to the width and length 
Table 1. The emergence percentages of each inbred and the influence of inoculation on seedling emergence. Seedling emergence values represent total emergence of both kernels with and without visual sign of $F$. moniliforme.

\begin{tabular}{|c|c|c|c|c|c|c|}
\hline \multirow[b]{2}{*}{ Inbred } & & \multicolumn{2}{|c|}{ \% Seedling Emergence } & \multirow[b]{2}{*}{$\% \triangle^{x}$} & \multirow{2}{*}{\multicolumn{2}{|c|}{$\begin{array}{l}\text { Influence of inoculation or } \\
\text { seedling emergence }\end{array}$}} \\
\hline & & Control & $\begin{array}{c}\text { Inoculated } \\
\text { treatment }\end{array}$ & & & \\
\hline IL101T & $\operatorname{sh} 2$ & 86 & 21 & 65 & 0.24 & $\mathrm{a}$ \\
\hline Ia453 & $\operatorname{sh} 2$ & 84 & 37 & 47 & 0.45 & $\mathrm{ab}$ \\
\hline Oh43 & su1 & 71 & 43 & 28 & 0.61 & bc \\
\hline IL784a & $\operatorname{sh} 2$ & 84 & 52 & 32 & 0.63 & bcd \\
\hline IL779a & se1 & 28 & 18 & 10 & 0.67 & bcde \\
\hline IL451b & $\operatorname{sh} 2$ & 50 & 33 & 17 & 0.68 & bcde \\
\hline IL451b & se1 & 89 & 60 & 29 & 0.69 & bcde \\
\hline C68 & $\operatorname{sh} 2$ & 90 & 66 & 24 & 0.73 & cdef \\
\hline p39m94 & $\operatorname{sh} 2$ & 84 & 63 & 21 & 0.75 & cdefg \\
\hline IL451b & su1 & 87 & 66 & 21 & 0.76 & cdefgh \\
\hline P39 & su1 & 83 & 66 & 17 & 0.80 & cdefgh \\
\hline Ia453 & su1 & 98 & 80 & 18 & 0.81 & cdefgh \\
\hline C68 & su1 & 97 & 80 & 17 & 0.82 & cdefgh \\
\hline IL731a & se1 & 91 & 76 & 15 & 0.84 & cdefgh \\
\hline IL678a & su1 & 98 & 84 & 14 & 0.85 & defgh \\
\hline $\mathrm{C} 23$ & su1 & 86 & 75 & 11 & 0.88 & efghi \\
\hline IL772b & se 1 & 98 & 87 & 11 & 0.89 & efghi \\
\hline IL781a & su1 & 92 & 82 & 10 & 0.89 & efghi \\
\hline IL677a & se 1 & 82 & 76 & 6 & 0.93 & fghi \\
\hline IL747b & se1 & 71 & 67 & 4 & 0.95 & fghi \\
\hline C40 & sh2 & 86 & 83 & 3 & 0.97 & fghi \\
\hline IL775a & se1 & 72 & 68 & 4 & 0.97 & ghi \\
\hline IL678a & se1 & 99 & 99 & 0 & 1.00 & hij \\
\hline Oh43 & sh2 & 73 & 81 & -8 & 1.12 & ij \\
\hline IL442s & sh2 & 51 & 62 & -11 & 1.24 & $\mathrm{j}$ \\
\hline \multirow[t]{3}{*}{ Overall $^{2}$} & su1 & $89 \quad b$ & 72 b & 17 & $0.81 \mathrm{a}$ & \\
\hline & se1 & $79 \mathrm{ab}$ & $69 \mathrm{~b}$ & 10 & $0.87 \mathrm{a}$ & \\
\hline & sh2 & $77 \mathrm{a}$ & 56 a & 21 & $0.76 \mathrm{a}$ & \\
\hline
\end{tabular}

${ }^{\mathrm{x}}$ The change in percent emergence of kernels with inoculation. This value was calculated by subtracting the mean percent germination of kernels of each inbred without sign of the pathogen in the inoculated treatment from the percent germination of kernels of the same inbred without visual sign of the pathogen in the control treatment.

${ }^{y}$ Influence of inoculation on seedling emergence. This value was calculated by dividing the mean percent germination of kernels of each inbred without sign of the pathogen in the inoculated treatment by the percent germination of the same inbreds without visual sign of the pathogen in the control treatment. Means for each inbred followed by dissimilar letters are significantly different at $P=0.05$ using Fisher's protected LSD test.

${ }^{z}$ Means for each endorsperm group followed by dissimilar letters are significantly different at $P=0.05$ using Fisher's protected LSD. 
dimensions of the containers with 50 holes drilled with even spacing for seed singulation. After placing the seed and removal of the form another $2.5 \mathrm{~cm}$ of soil mixture was spread over the seeds. The amount of water necessary to provide $70 \%$ of soil saturation $(280 \mathrm{ml})$ was carefully poured into each container. The boxes were covered with lids and placed in a Percival incubator (Boone, Iowa) at $25^{\circ} \mathrm{C}$.

After seven days the boxes were removed and the number of emerged seedlings in each box counted and recorded. The emergence percentages of kernels with and without visual sign for each treatment and inbred were determined since the kernels of each type were separated in each box. The plants from each box were rinsed of soil, surface dried with paper towels and dissected into root, shoot, and kernel tissue and each portion weight. Seedling weight determine by summing the weight of the root and shoot tissue for each inbred and replicate and dividing by the number of seedling in each box.

\section{Result and Discussion}

The importance of the proportion of kernels displaying visual sign of the pathogen is related to the quality of the seed and its ability to successfully germinate and emerge from the soil. When averaged over all inbreds, seedling emergence of kernels displaying visual signs of the pathogen in the inoculated treatment was only $31 \%$ of the control (data not shown). This percentage was nearly identical for each endosperm class. Kernels of Oh43 sh2, IL678a se1, and C40 sh2 with visual signs of the pathogens from the inoculated treatment had 90 to $100 \%$ seedling emergence. The seed of these genotypes can successfully germinate and emerge even with visual levels of infection. This represents a second mode of resistance distinct from that observed in previous study (Han, submitted).

Germination and seedling emergence of the inbreds were found to be differentially influenced by prior inoculation of silk with $F$. moniliforme (Table 1). The percent emergence of control seed lots averaged over all inbreds was $82 \%$ in comparison with $65 \%$ in the inoculated treatment, a $21 \%$ reduction. All but two of the inbreds (Oh43 sh2, IL442a sh2) displayed reduced mean seedling emergence with inoculation. Percent emergence was observed to range among inbreds from 28 to $99 \%$ in the control and from 18 to $99 \%$ in the inoculated treatment. To isolate only the influence of inoculation, inbred performance of the inoculated treatment was divided by that of the control for each inbred and statistically analyzed (Table 1, column 5). The ratio of inoculation divided by control emergence ranged from 0.24 in IL101T sh2 to 1.24 in IL442a sh2. A t-test run between IL678a se1, which displayed no influence from inoculation on seedling emergence, and IL442a sh2 indicated these lines were significantly different (t-statistic $=7.88$, $\mathrm{P}=0.048)$ in their performance. This suggests inoculation with F. moniliforme of IL442a sh2 stimulated the germination and emergence of this seed compared to the control. F. moniliforme may serve as a deterrent to kernel invasion by other seed-infection fungi (Rheeder et al., 1990). Isolates of Rhizopus arrihzus, F. oxysorum and Aspergillus niger added to soil enhanced seed germination and growth in greenhouse pathogenicity trials in the presence of $F$. moniliforme (Baird, 1992). This could explain one possible mechanism of the IL442a sh2 stimulation of germination. The variation in the response of the inbreds to inoculation suggests genetic difference are conditions their susceptibility to the influence of $F$. moniliforme on seedling emergence.

The LSD test (Table 1) also showed the emergence of IL101T sh2, Ia453 sh2, Oh43 su1, IL784a sh2, IL779a se1, IL451b sh2, IL451b se1, 
C68 sh2, and p39m94 sh2 inoculated seed was significantly reduced compared to their controls without inoculation. Although an LSD test comparing the averaged performance of the inbreds by endosperm classes uncovered no significant differences, six of the nine genotypes with significant reductions in emergence from inoculation were homozygous for sh2. Removal of the one sh2 line (IL442a sh2) which displayed stimulation with inoculation from the comparison of endosperm classes resulted in the emergence of the sh2 lines to be significantly lower than observed in the other endosperm classes. This tentatively suggests inbreds with the sh2 mutation may be somewhat more susceptible to the effect of colonization by the pathogen on germination and seedling emergence. However, as evidenced by the comparative performance of IL101T sh2 and IL442a sh2, there are other genetic factors aside from the type of endosperm mutation that can significantly affect inbred response to inoculation.

Fresh seedling weight (root plus shoot fresh weight) for each inbred in the control and inoculated treatments and their ratios are calculated (Table 2). Averaged over all the genotypes seedling weights after seven days at $25^{\circ} \mathrm{C}$ in the incubator were $8.5 \%$ less than the control. Inoculation with $F$. moniliforme did not influence seedling weight as dramatically as it affected the proportion of kernels with visual sign of the pathogen or seedling emergence. Only two genotypes, IL779a se1 and IL451b se1 displayed seedling weights significantly influenced by inoculation. The significantly increased seedling weight of only those two lines is difficult to explain and may be due to experimental error and random chance.

Styer and Cantliffe (1984) tested a set of inbreds and commercial hybrids for the incidence of kernel asymptomatic infection by $F$. moniliforme. Using fungal specific media they observed $90 \%$ of the genotypes contained F. moniliforme and suggested visual undetectable infection by the pathogen may reduce field germination and emergence. To ascertain in this study the importance of asymptomatic kernel infection by F. moniliforme, emergence of visually uninfected kernels in the inoculated treatment was divided by the emergence of visually uninfected kernels in the control (Table 3). In this study since the seed lots were not cultured on F. moniliforme specific media to evaluate for the presence of the pathogen in kernels without visual sign, significant differences are presumed to be due to asymptomatic kernel infection reduced emergence by only $11.3 \%$. No differences were observed between endosperm classes. The emergence of only three of the inbreds (Oh43 sh2, IL747b se1, IL442a sh2) was significantly influenced by asymptomatic infection. The enhanced emergence of IL442a sh2 described above and displayed in table 3 appeared to be largely the result of stimulated emergence among asymptomatic kernels. Asymptomatic infection was also responsible for a significant reduction in the emergence of the IL101T sh2 inoculated seed.

In conclusion, there are second resistance mode after $F$. moniliforme infection. In some cases, $F$. moniliforme even stimulated the germination. Endosperm mutation of sweet corn was not the only factor affecting germination rate, which means there are big variation in it. F. moniliforme infection influenced on seedling weight in a minor way. This genetic variation can be adopted in the breeding program in future.

\section{Acknowledgements}

This research was supported by Bio-industry Technology Development Program, Ministry for Food, Agriculture, Forestry and Fisheries, and by the LMO environment risk assessment of assign the RDA, Republic of Korea. 
Table 2. The fresh seedling weights of each inbred and the influence of inoculation on seedling weight.

\begin{tabular}{|c|c|c|c|c|c|c|}
\hline \multirow[b]{2}{*}{ Inbred } & & \multicolumn{2}{|c|}{ Seedling weight (mg/plant) ${ }^{w}$} & \multirow[b]{2}{*}{$\% \triangle^{x}$} & \multirow{2}{*}{\multicolumn{2}{|c|}{$\begin{array}{l}\text { Influence of inoculation } \\
\text { on seedling weight }\end{array}$}} \\
\hline & & Control & $\begin{array}{l}\text { Inoculated } \\
\text { treatment }\end{array}$ & & & \\
\hline IL772b & se1 & 84 & 55 & 29 & 0.66 & $\mathrm{a}$ \\
\hline Ia453 & su1 & 112 & 74 & 38 & 0.68 & $a b$ \\
\hline C68 & sh2 & 61 & 42 & 19 & 0.69 & $\mathrm{ab}$ \\
\hline IL678a & su1 & 87 & 60 & 27 & 0.69 & abc \\
\hline Ia453 & sh2 & 57 & 40 & 17 & 0.71 & acd \\
\hline IL101T & sh2 & 68 & 53 & 15 & 0.78 & abcd \\
\hline p39m94 & sh2 & 38 & 30 & 8 & 0.79 & abcd \\
\hline IL747b & se1 & 71 & 56 & 15 & 0.79 & abcd \\
\hline IL451b & sh2 & 38 & 29 & 9 & 0.80 & abcd \\
\hline IL781a & su1 & 75 & 63 & 12 & 0.83 & abcd \\
\hline IL451b & su1 & 78 & 69 & 9 & 0.89 & abcd \\
\hline IL784a & sh2 & 73 & 66 & 7 & 0.90 & abcd \\
\hline IL775a & se1 & 53 & 48 & 5 & 0.92 & abcd \\
\hline P39 & su1 & 88 & 82 & 6 & 0.93 & abcd \\
\hline Oh43 & su1 & 63 & 60 & 3 & 0.96 & abcd \\
\hline Oh43 & sh2 & 55 & 53 & 2 & 0.96 & abcd \\
\hline C40 & $\operatorname{sh} 2$ & 59 & 59 & 0 & 1.01 & abcd \\
\hline IL678a & se1 & 79 & 81 & -2 & 1.04 & abcd \\
\hline C23 & su1 & 77 & 80 & -3 & 1.05 & bcd \\
\hline IL731a & se 1 & 61 & 64 & -3 & 1.07 & cde \\
\hline IL677a & se 1 & 68 & 74 & -6 & 1.10 & de \\
\hline C68 & su1 & 64 & 71 & -7 & 1.11 & de \\
\hline IL442a & sh2 & 41 & 47 & -6 & 1.16 & e \\
\hline IL779a & se 1 & 36 & 51 & -15 & 1.44 & e \\
\hline IL451b & se1 & 31 & 68 & -37 & 2.31 & $\mathrm{f}$ \\
\hline \multirow[t]{3}{*}{ Overall $^{\mathrm{z}}$} & su1 & $81 \mathrm{~b}$ & $70 \quad \mathrm{c}$ & 11 & \multicolumn{2}{|c|}{0.89 а } \\
\hline & se 1 & $60 \mathrm{a}$ & $62 \mathrm{~b}$ & -2 & \multicolumn{2}{|c|}{$1.16 \mathrm{~b}$} \\
\hline & sh2 & $54 \mathrm{a}$ & $47 \mathrm{a}$ & 8 & \multicolumn{2}{|c|}{0.86 а } \\
\hline
\end{tabular}

${ }^{w}$ Seedling weight consisted of shoot plus root fresh weight.

${ }^{x}$ The change in fresh seedling weight with inoculation. This value was calculated by subtracting mean seedling weights of each inbred in the inoculated treatment from the mean seedling weights of the same inbred without inoculation.

${ }^{\mathrm{y}}$ Influence of inoculation on fresh seedling weight. This value was calculated by dividing the mean seedling weight of each inbred in the inoculated treatment by the mean seedling weight of the same inbred without inoculation. Means for each inbred followed by dissimilar letters are significantly different at $P=0.05$ using Fischer's protected LSD test.

${ }^{\mathrm{z}}$ Means for each endosperm group followed by dissimilar letters are significantly different at $P=0.05$ using Fisher's Protected LSD. 
Table 3. The emergence percentages of inoculated and control kernels without visual sign of $F$. moniliforme for each inbred and the influence of inoculation on seedling emergence for kernels without visual sign of the pathogen.

\begin{tabular}{|c|c|c|c|c|c|c|}
\hline \multirow[b]{2}{*}{ Inbred } & & \multicolumn{2}{|c|}{ \% Seedling Emergence (Kemels without sign) } & \multirow[b]{2}{*}{$\% \triangle^{x}$} & \multirow{2}{*}{\multicolumn{2}{|c|}{$\begin{array}{l}\text { Influence of inoculation } \\
\text { on seedling emergence }\end{array}$}} \\
\hline & & Control & $\begin{array}{c}\text { Inoculated } \\
\text { treatment }\end{array}$ & & & \\
\hline IL101T & sh2 & 87 & 36 & 51 & 0.41 & $\mathrm{a}$ \\
\hline $\mathrm{Oh} 43$ & su1 & 70 & 50 & 20 & 0.72 & $\mathrm{~b}$ \\
\hline IL451b & se1 & 92 & 70 & 22 & 0.76 & bc \\
\hline p39m94 & sh2 & 91 & 70 & 21 & 0.76 & bc \\
\hline C68 & sh2 & 91 & 70 & 21 & 0.77 & bcd \\
\hline IL779a & se1 & 27 & 21 & 6 & 0.78 & bcd \\
\hline Ia453 & sh2 & 84 & 65 & 19 & 0.78 & bcd \\
\hline IL451b & su1 & 90 & 71 & 19 & 0.80 & bcd \\
\hline IL451b & sh2 & 49 & 38 & 11 & 0.80 & bcd \\
\hline IL784a & sh2 & 88 & 70 & 18 & 0.80 & bcd \\
\hline Ia453 & su1 & 99 & 83 & 16 & 0.84 & bcde \\
\hline C68 & su1 & 97 & 83 & 14 & 0.86 & bcde \\
\hline C23 & su1 & 90 & 78 & 12 & 0.86 & bcde \\
\hline IL731a & se 1 & 91 & 80 & 11 & 0.87 & bcde \\
\hline IL678a & su1 & 99 & 89 & 10 & 0.91 & bcde \\
\hline IL775a & se1 & 79 & 72 & 7 & 0.93 & bcde \\
\hline IL781a & su1 & 92 & 86 & 6 & 0.93 & bcde \\
\hline P39 & su1 & 89 & 85 & 4 & 0.96 & cdef \\
\hline IL772b & se1 & 98 & 95 & 3 & 0.97 & cdefg \\
\hline $\mathrm{C} 40$ & sh2 & 86 & 83 & 3 & 0.97 & cdefg \\
\hline IL678a & se1 & 99 & 100 & 1 & 1.01 & defg \\
\hline IL677a & se 1 & 82 & 85 & -3 & 1.04 & efgh \\
\hline Oh43 & sh2 & 74 & 86 & -12 & 1.18 & fgh \\
\hline IL747b & se1 & 73 & 88 & -15 & 1.21 & gh \\
\hline IL442a & sh2 & 54 & 67 & -13 & 1.26 & h \\
\hline \multirow[t]{3}{*}{ Overall $^{\mathrm{z}}$} & su1 & $91 \quad \mathrm{~b}$ & $78 \quad b$ & 13 & 0.95 & \\
\hline & se1 & 80 a & $76 \mathrm{~b}$ & 4 & 0.86 & \\
\hline & sh2 & 76 a & 65 a & 13 & 0.86 & \\
\hline
\end{tabular}

${ }^{x}$ The change in percent emergence of kernels with inoculation. This value was calculated by subtracting the mean percent germination of kernels of each inbred without sign of the pathogen and the inoculated treatment from the percent germination of kernels of the same inbred without visual sign of the pathogen in the control treatment.

${ }^{y}$ Influence of inoculation on seedling emergence. This value was calculated by dividing the mean percent germination of kernels of each inbred without sign of the pathogen in the inoculated treatment by the percent germination of the same inbreds without visual sign of the pathogen in the control treatment. Means for each inbred followed by dissimilar letters are significantly different at $P=0.05$ using Fischer's protected LSD test.

${ }^{\mathrm{z}}$ Means for each endosperm group followed by dissimilar letters are significantly different at $P=0.05$ using Fisher's Protected LSD. 


\section{Summary}

Infected sweet corn seed may increase the incidence of seedling blight and contribute to systemic infection of plants. Inbreds of field or dent corn also had kernels infected with $F$. moniliforme. Although F. moniliforme causes a kernel rot, the pathogen is often found in healthy kernels that appear to be physically undamaged. Sweet corn inbreds have been identified that exhibit partial resistance to kernel infection by $F$. moniliforme and good emergence. The work described a genetically diverse set of sweet corn inbreds for seedling emergence to $F$. moniliforme infection with either su1, se1 and sh2 endorsperm mutations. There were second resistance mode after $F$. moniliforme infection, in some cases, F. moniliforme even stimulated the germination.

\section{References}

1. Baird, R.E. 1992. Effects of foliar fungicides on wheat, 1991. Fungicide and Nematicide Tests 47: 178.

2. Berger, R.D. and Wolf, E.A. 1974. Control of seedborne and soilborne mycoses of 'Florida Sweet' corn by seed treatment. Plant Dis. Rep. 58: 922-923.

3. Christensen, J.J. and Wilcoxson, R.D. 1966. Stalk rot of corn. Phytopathological Monograph 3. Published for the Am. Phytopathological Soc. by Heffernan Press, Inc., Worcester, MA. 59 pp.

4. Creech, R.G. 1965. Genetic control of carbohydrate synthesis in maize endosperm. Genetics 52: 1175-1186.

5. Dickinson, D.B., Boyer, C.D., and Velu, J.G. 1983. Reserve carbohydrate from kernels of sugary and sugary enhancer maize. Phytochemistry 22: 1371-1373.

6. Douglass, S.K., Juvik, J.A. and Splittstosser,
W.E.. 1993. Sweet corn seedling emergence and variation in kernel carbohydrate reserves. Seed Sci. and Technol. 21: 433-445.

7. Ferguson, J.E., Dickinson, D.B. and Rhodes, A.M. 1979. Analysis of Endosperm Sugars in a Sweet Corn Inbred (Illinois 677a) Which contains the Sugary Enhancer (se) Gene and Comparison of se with Other Corn Genotypes.

8. Foley, D.C. 1962. Systemic infection of corn by Fusarium moniliforme. Phytopathology 52: 870-872.

9. Futrell, M.C. and Kilgore, M. 1969. Poor stands of corns and reduction of root growth caused by Fusarium moniliforme. Plant Dis. Rep. 53: 213-215.

10. Garwood, D.L., McArdle, F.J., Vanderslice, S.F., and Shannon, J.C. 1976. Postharvest carbohydrate transformations and processed quality of high sugar maize genotypes. J. Amer. Soc. Hort. Sci. 101: 400-404.

11. Gonzales, J.W., Rhodes, A.M. and Dickinson, D.B. 1974. A new inbred with high sugar content in sweet corn. HortScience 9: 79-80.

12. Gonzales, J.W., Rhodes, A.M. and Dickinson, D.B. 1976. Carbohydrate and enzymatic characterization of a high sucrose sugary inbred line in sweet corn. Plant Physiol. 58: 28-32.

13. Han, T.H. 2014. The effect of Fusarium moniliforme infection in sweet corn. Agricultural Science \& Technology Reserch. Submitted.

14. Headrick, J.M. and Pataky, J.K. 1989. Resistance to kernel infection by Fusarium moniliforme in sweet corn inbred lines and the effect of infection on emergence. Plant Disease 73: 887-892.

15. Headrick, J.M., Pataky J.K. and Juvik, J.A. 1989. Effects of kernel carbohydrate content and post pollination silk condition on the response of sweet corn inbred lines to kernel infection by Fusarium moniliforme. Phytopathology. 79. 
16. Jangulo, M.C. 1988. The effect of different endosperm mutations on sweet corn seedling emergence and vigor.

17. Koehler, B. 1942. Natural mode of entrance of fungi into corn ears and some symptoms that indicate infection, J. Agric. Res. 64:421-442.

18. Rheeder, J.P., Marasas, W.F.O., and Van Wyk, P.S. 1990. Fungal association in corn kernels and effects on germination. Phytopathology 80:131-134.

19. Shurtleff, M.C. 1977. A Compendium of Corn Diseases. American Phytopathlogical Society, St. Paul, MN. 64 pp.

20. Simon, E.W. 1978. Plant membranes under dry conditions. Pesticide Sci. 9:168-172.

21. Smith, F.L. and Madsen, C.B. 1949. Susceptibility of inbred lines of corn to
Fusarium ear rot. Agron. J. 41:347-348.

22. Soberalske, R.M. and Andrews, R.H. 1978. Gene effects on kernel moisture and sugars in near isogenic lines of sweet corn. Crop Sci. 18:743-746.

23. Styer, R.C. and Cantliffe, D.J. 1984. Infection of two endosperm mutants of sweet corn by Fusarium moniliforme and its effect on seedling vigor. Phytopathology 74:189-194.

24. Thomas, M.D. and Buddenhagen, I.W. 1980. Incidence and persistence of Fusarium moniliforme in symptomless maize kernels and seedlings in Nigeria. Mycologia 72:882-887.

25. Wolf, E.A. and Showalter, R.K. 1974. Florida Sweet, a high quality sh2 sweet corn hybrid for fresh market. Fla. Agric. Exp. Sta. Cir. S-226. 